p-ISSN: $2338-4794$

e-ISSN: 2579-7476

Vol.8. No. 1 Januari-April 2020

\title{
PENGARUH EXPERIENTIAL MARKETING DAN TOURIST SATISFACTION TERHADAP REVISIT INTENTION TOURISM DI DANAU KELIMUTU
}

\author{
Maria Endang Jamu ${ }^{1)}$ \\ 1) Dosen Program Studi Manajemen Universitas Flores \\ E-mail: endangjamu2@gmail.com \\ Yulius Laga ${ }^{2)}$ \\ 2) Dosen Program Studi Manajemen Universitas Flores \\ E-mail: endangjamu2@gmail.com
}

\begin{abstract}
The objective of the research is to find out the influence of experential marketing and tourist satisfaction positively and significantly to the revisit intention of tourists in the Kelimutu National Park Area. The method used in this study is quantitative descriptive, with respondents in this research were domestic tourists with a total of 140 as a basis for consideration for SEM-PLS. The sample was taken using purposive sampling. The results of the research showed that experential marketing and tourist satisfaction are positive and significant for revisit intention tourist in the Kelimutu National Park.
\end{abstract}

Keywords : Experiential marketing, tourist satisfaction, revisit intention

\section{PENDAHULUAN}

Kawasan Taman Nasional Kelimutu (TNK) yang berada di Kabupaten Ende Provinsi Nusa Tenggara Timur merupakan destinasi pariwisata yang terkenal baik di tingkat regional, nasional maupun internasional. Objek wisata yang pernah menjadi salah satu nominasi keajaiban dunia ini, merupakan kebanggaan masyarakat sekitar bahkan masyarakat Provinsi Nusa Tenggara Timur.

Kawasan Taman Nasional Kelimutu dikenal karena keindahan serta fenomena alam yang tidak dimiliki oleh daerah lain yaitu terdapat tiga buah kawah danau yang terbentuk karena erupsi gunung Kelimutu beberapa abad yang lalu. Keunikan dan fenomena alam yang terjadi menjadikan wisata menjadi destinasi yang banyak dikunjungi wisatawan, sehingga berimplikasi terhadap pergerakan kunjungan wisatawan yang terus meningkat dari tahun ke tahun.

Berdasarkan data yang diperoleh dari (Badan Pusat statistik Kabupaten Ende, 2018) menunjukkan adanya peningkatan jumlah kunjungan wisatawan domestik ke danau Kelimutu pada tahun 2017 sejumlah 73,417 atau sekitar $34 \%$ dari tahun sebelumnya. Jumlah wisatawan yang terus meningkat memberikan dampak yang positif dalam penerimaan pendapatan daerah kabupaten Ende.

Adanya peningkatan kunjungan wisatawan ke danau Kelimutu dan pengembangan destinasi wisata lainnya yang ada di Nusa Tenggara Timur khususnya di Kabupaten Ende, menuntut pihak pengelola dalam hal ini adalah dinas pariwisata dan Balai Taman Nasional Kelimutu untuk lebih kompetitif dalam menyediakan serta memberikan pelayanan yang berkualitas kepada wisatawan, sehingga berdampak pada kepuasan dan loyalitas wisatawan untuk berkunjung kembali, karena menurut (Ali, 2015) kepuasaan wisatawan menjadi hal yang penting untuk diperhatikan karena akan memberikan dampak yang besar pada niat wisatawan untuk berkunjung kembali.

Pelayanan yang berkualitas menjadi salah satu strategi dalam kegiatan pemasaran karena tidak hanya terbatas pada bagaimana 
menjual dan memberitahu (telling and selling) produk, tetapi bagaimana cara untuk memahami konsumen, menciptakan, mengkomunikasikan dan memberikan nilai dan kepuasan kepada konsumen (Kotler dan Keller, 2017; Kotler \& Keller, 2008, 2009). Menurut (Bernd Schmitt, 2007) konsep experiential marketing bukan hanya sebatas memberikan manfaat terhadap suatu produk dan jasa, tetapi sebuah experience atau pengalaman untuk memenuhi kebutuhan emosional konsumen.

Beberapa penelitian terdahulu yang berkaitan dengan pengaruh experential marketing dan tourist satisfaction terhadap revisit intention yaitu penelitian yang dilakukan oleh (Žabkar, Brenčič, \& Dmitrović, 2010) (Jamu, 2014) menunjukkan bahwa kepuasan terhadap destinasi tertentu akan berdampak pada loyalitas seorang wisatawan. Loyalitas akan menyebabkan niat untuk melakukan kunjungan ulang, tinggal lebih lama di daerah destinasi dan kemungkinan merekomendasikan destinasi yang telah dikunjunginya kepada orang lain. Menurut Zeithaml et al dalam (Wulanjani \& Derriawan, 2017) revisit intention merupakan bentuk perilaku atau keinginan pelanggan untuk datang kembali, memberikan word of mouth yang positif, tinggal lebih lama dan berkunjung lebih sering. Menurut Tjiptono (2008) dalam (Handayani \& Pratama, 2019) pelanggan yang puas aka melakukan pembelian ulang serta membentuk perilaku pelanggan untuk merekomendasikan dari mulut ke mulut, yang tentu saja akan memberikan keuntungan bagi sebuah perusahaan. Berdasarkan data dan penelitian terdahulu di atas, maka peneliti ingin meneliti tentang pengaruh experential marketing dan tourist satisfaction terhadap revisit intention tourism di kawasan Taman Nasional Kelimutu.

\section{LANDASAN TEORI}

\section{Experiential Marketing}

Menurut (Bh Schmitt, 1999) dalam (Ari Wijaksono, 2018) menuturkan bahwa
Experiential marketing adalah bagaimana cara pemasar dalam mendapatkan konsumen melalui pengalaman panca indera (sense), pengalaman perasaan (feel), pengalaman pikiran (think), pengalaman dengan perilaku dan gaya hidup (act), dan pengalaman yang dapat merefleksikan merek tersebut yang merupakan pengembangan dari sensations, feelings, cognitions, dan actions (relate) terhadap perusahaan atau merek.

Experiential marketing tidak hanya sekedar memenuhi kebutuhan pelanggan saja, tetapi juga berusaha menciptakan pengalaman yang berkesan kepada pelanggan dengan menyentuh emosi mereka serta memberikan perasaan yang positif secara personal terhadap suatu produk yang mereka konsumsi karena akan berdampak pada hubungan jangka panjang dengan pelanggan (Jamu, 2014). Menurut (Hendarsono \& Sugiharto, 2013) fokus utama dari suatu experiential marketing adalah pada tanggapan panca indra, pengaruh, tindakan serta hubungan. Schmitt dalam (Rohmat Dwi Jatmiko \& Sri Nastiti Andharini, 2012) mengatakan bahwa untuk mengukur experiential marketing menggunakan dimensi Sense, Feel, Think, Act dan Relate.

\section{Tourist Satisfaction}

Kepuasaan wisatawan akan sebuah destinasi wisata akan berdampak pada loyalitas yang akan menyebabkan niat untuk melakukan kunjungan ulang, tinggal lebih lama di daerah destinasi dan kemungkinan merekemendasikan destinasi yang telah dikunjunginya kepada orang lain (Kotler dan Keller, 2017) (Çoban, 2012) (Hernández-Lobato, Solis-Radilla, Moliner-Tena, \& Sánchez-García, 2006) (Žabkar et al., 2010) (Basiya \& Rozak, 2012). Pernyataan yang sama juga oleh (Som \& Badarneh, 2011) (Wong \& Yan Kwong, 2004) (Yoon \& Uysal, 2005)(Hui, Wan, \& Ho, 2007) mengatakan bahwa wisatawan yang merasa puas akan merekomendasikan wisata tersebut ke 
wisatawan lain, dan punya niat untuk berkunjung kembali.

Berdasarkan rujukan dari penelitianpenelitian terdahulu, maka beberapa indikator yang digunakan untuk mengukur tourist satisfaction adalah niat untuk melakukan kunjungan ulang,tinggal lebih lama di daerah destinasi dan kemungkinan merekemendasikan destinasi yang telah dikunjunginya kepada orang lain.

\section{Revisit Intention}

Secara konseptual kunjungan ulang didefinisikan sebagai niat untuk melanjutkan pembelian, keinginan membeli produk lebih banyak dan keinginan untuk merekomendasikan produk tersebut kepada orang lain. (Som \& Badarneh, 2011) (Li, Cheng, Kim, \& Petrick, 2008) (Hasan Ali \& Haryadi, 2012). Menurut Baker dan Crompton (2000) dalam (Annisa \& Hutasoit, 2018) mengatakan bahwa persepsi kualitas layanan dan kepuasaan telah menjadi acuan bagi wisatawan untuk memiliki niat bekunjung kembali ke destinasi yang sama.

Berdasarkan rujukan dari penelitianpenelitian terdahulu, maka beberapa indikator yang digunakan untuk mengukur revisit intention diantaranya adalah pernyataan bahwa wisatawan memiliki keinginan untuk berkunjung kembali, akan mengajak teman-teman, mengajak keluarga dan menceritakan pengalaman berwisatanya kepada orang lain.

\section{Model Penelitian}

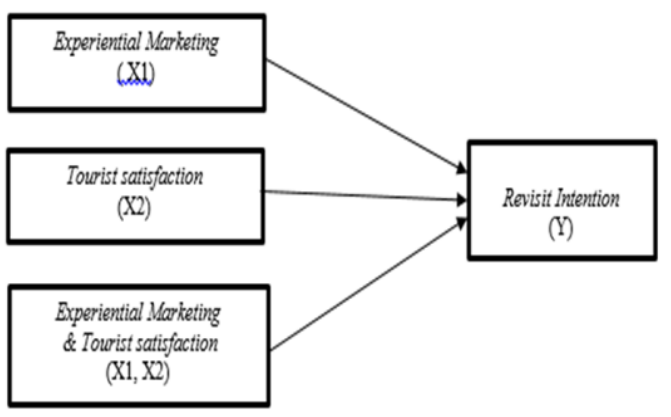

Gambar 1. Model Penelitian

\section{Hipotesis}

Dalam penelitian ini, terdapat tiga variabel yang dapat diukur yaitu Experiential marketing, Tourist satisfaction dan Revisit intention. Maka hipotesis penelitian ini adalah:

H1 : Terdapat pengaruh yang positif dan signifikan antara experiential marketing terhadap Revisit intention wisatawan di kawasan Taman Nasional Kelimutu

H2 : Terdapat pengaruh yang positif dan signifikan antara Tourist satisfaction

terhadap Revisit intention wisatawan di kawasan Taman Nasional Kelimutu

H3 : Terdapat pengaruh yang positif dan signifikan antara experiential marketing dan Tourist satisfaction terhadap Revisit intention wisatawan di kawasan Taman Nasional Kelimutu

\section{METODE PENELITIAN}

Penelitian ini menggunakan data kuantitatif untuk menguji hipotesa antara variabel penelitian. Variabel penelitian ini adalah experiential marketing dan tourist satisfaction berpengaruh terhadap revisit intention. Instrumen yang digunakan dalam penelitian ini adalah kuisioner, yang disebarkan kepada wisatawan domestik yang sedang berkunjung atau yang sudah pernah berkunjung ke kawasan Taman Nasional Kelimutu.

Sampel dalam penelitian ini adalah para wisatawan yang pertama kali atau lebih dari satu kali berkunjung ke kawasan Taman Nasional Kelimutu. Teknik pengambilan sampel menggunakan teknik purposive sampling, yaitu metode pengambilan sampel yang dilakukan berdasarkan pertimbangan peneliti yang dipilih secara cermat dan memiliki kriteria tertentu sesuai kebutuhan penelitian, serta mudah dijangkau oleh peneliti (Sugiyono, 2016)

Data penelitian dianalisis menggunakan SEM- PLS dengan WarpPLS 3.0 (Partial Least Square - Stuctural Equation Modeling). Alat analisis ini digunakan karena disesuaikan dengan besarnya sampel penelitian. Berkaitan 
dengan hal tersebut, ukuran sampel untuk SEM (Stuctural Equation Modeling) yang menggunakan ,model estimasi maximum likehoad (ml) antara 100- 200 sampel (Ghozali, 2016)

Menurut Kock dalam (Sholihin \& Ratmono, 2013) berpendapat bahwa signifikansi keterdukungan hipotesis dapat dilakukan dengan cara melihat model struktural yang terdiri dari hubungan yang dihipotesiskan diantara konstruk-konstruk laten dalam model penelitian. Analisis SEMPLS, dapat memperoleh koefisien jalur (path coefficients), yang selanjutnya dapat digunakan oleh peneliti untuk menilai signifikansi statistik model penelitian dengan menguji hipotesis untuk tiap jalur hubungan. Hipotesis penelitian dapat diterima jika Pvalues $\leq 0.05$

\section{HASIL DAN PEMBAHASAN}

Bagian ini memaparkan hasil pengolahan data yang diperoleh dari wisatawan yang dijadikan sebagai sampel dalam penelitian melalui kuisioner yang disebarkan dan diolah menggunakan analisis SEM-PLS (Partial Least Square- Stuctural Equation Modeling) dengan WarpPLS 3.0 yang digunakan untuk menguji hipotesis yang telah diajukan sebelumnya. Uji hipotesis digunakan untuk melihat pengaruh antara variabel laten dan untuk uji hipotesis dapat mengunakan model structural (inner model). Pengaruh antara variabel laten dapat dilihat dari nilai R-square. Semakin besar nilai Rsquare, maka semakin besar pengaruh variabel laten eksogen terhadap variabel laten endogen serta signifikansi dari koefisien parameter jalur struktural.

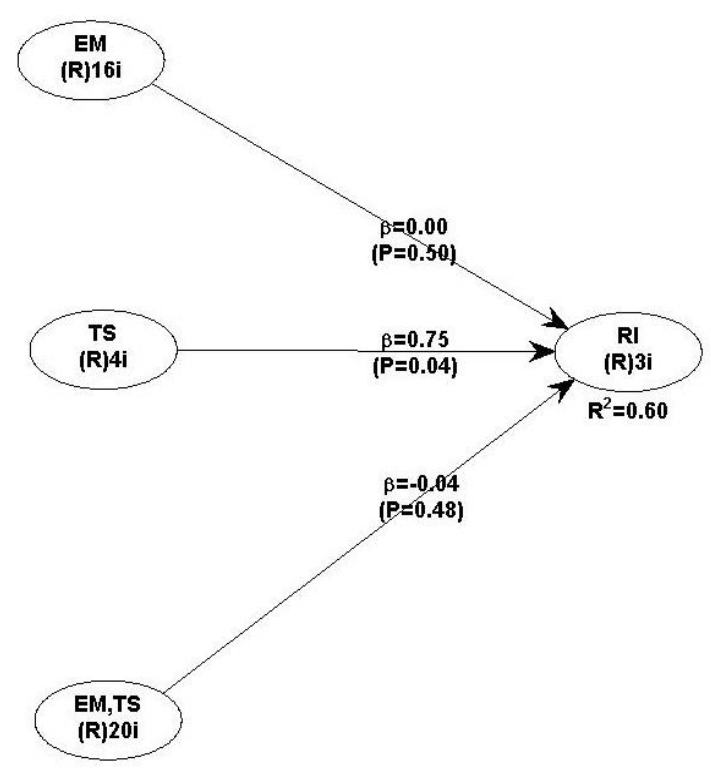

Gambar 2. Hasil Olahan SEM-PLS dengan WarpPLS 3.0

Berdasarkan jalur koefisien hasil analisis yang telah dilakukan, diperoleh bahwa experiential marketing berpengaruh terhadap revisit intention atau niat berkunjung ulang wisatawan ke danau Kelimutu dengan Pvalues sebesar 0.50 dengan nilai koefisiennya sebesar 0.00, hal ini menunjukkan bahwa experiential marketing berpengaruh positif dan signifikan terhadap niat berkunjung ulang wisatawan di danau Kelimutu atau dengan kata lain hipotesis pertama diterima. Hal ini mengindikasikan bahwa variabel experiential marketing adalah variabel yang paling kuat pengaruhnya pada niat berkunjung ulang para wisatawan di danau Kelimutu.

Hasil penelitian ini sejalan dengan hasil penelitian yang dilakukan oleh (Gaol, 2014) yang mengatakan bahwa ketertarikan wisatawan yang berkunjung ke danau Kelimutu adalah selain tertarik untuk menikmati pesona keindahan alam dan keajaibannya. Selain itu juga, ada yang tertarik untuk mengetahui lebih jauh tentang misteri dibalik keberadaan ketiga danau tersebut. Ketertarikan tersebut tidak lepas dari mitos atau cerita masyarakat setempat mengenai keberadaan danau tersebut. Hasil penelitian ini, seiring dengan hasil penelitian yang dilakukan oleh (Jamu, 2014) yang berpendapat bahwa experiential marketing berpengaruh 
terhadap niat berkunjung ulang wisatawan di Pulau Komodo, dan dalam penelitian (Chen, Huan, \& Thongma, 2011) mengemukakan bahwa experiential marketing berpengaruh positif terhadap revisit intention yaitu semakin tinggi nilai experiential marketing maka tinggi pula revisit intention. Hasil penelitian ini juga sejalan dengan hasil penelitian dari (Budiarto \& Pancaningrum, 2019) yang menunjukkan bahwa variabel experiential marketing (sense, feel, think, act and relate) berpengaruh positif dan signifikan terhadap keputusan pembelian smartphone Xiomi. Hasil penelitian yang dikemukakan oleh (Tosun, Dedeoğlu, \& Fyall, 2015) juga mengatakan bahwa kualitas pelayanan menjadi hal utama yang diperhatikan oleh wisatawan, sehingga hal tersebut akan berdampak pada niat berkunjung kembali wisatawan ke destinasi tersebut. Hasil penelitian lainnya yang dilakukan oleh (Jeon, 2013) menunjukkan bahwa experiental marketing berpengaruh signifikan terhadap niat berkunjung kembali dan kelima dimensi pada experiential marketing yaitu (sense, feel, think, act and relate) memungkinkan terbentuknya keinginan para wisatawan untuk mengunjungi kembali di masa yang akan datang.

Pengalaman-pengalaman positif yang diterima wisatawan akan memberikan dampak yang positif bagi wisatawan, pengelolah objek wisata dan objek wisata itu sendiri. Pengalaman positif yang dirasakan oleh wisatawan saat berwisata atau berkunjung ke Taman Nasional Kelimutu untuk menikmati indahnya pemandangan, tenangnya suasana alam, dan keunikan dari fenomena alam yang terjadi, cerita mitos, keramahan dari para petugas karcis, serta pengalaman berwisata membuat para wisatawan semakin mencintai dan menghargai alam serta memberikan kepuasaan yang pada akhirnya berdampak pada niat untuk melakukan kunjungan ulang. Berkaitan dengan hal ini, pengelola Taman Nasional Kelimutu dituntut untuk memperhatikan hal-hal yang berkaitan dengan kepuasaan dan kenyamanan para wisatawan, mulai dari kebersihan sekitar kawasan wisata, keramahan petugas karcis dalam melayani pembelian karcis masuk di kawasan wisata, serta diharapkan agar masyarakat lokal dapat bersikap ramah dan sopan kepada setiap wisatawan yang dijumpai di sekitar kawasan wisata. Keramahan masyarakat lokal dapat memberikan kesan dan dampak yang positif bagi wisatawan, karena mereka memiliki pengalaman lain selain melihat keindahan danau Kelimutu.

Besarnya pengaruh tourist satisfaction terhadap revisit intention adalah sebesar 0.04 dengan nilai koefisien dari P-values sebesar 0.75, hal ini menunjukkan bahwa tourist satisfaction atau kepuasaan wisatawan kurang berpengaruh positif terhadap revisit intention atau niat berkunjung ulang ke danau Kelimutu. Hal ini menunjukkan bahwa wisatawan yang berkunjung ke danau Kelimutu baik yang pertama kali ataupun lebih dari satu kali merasa kurang puas dengan pengalaman berwisata ke destinasi yang sama, karena adanya perasaan bosan dan juga tidak ada tempat tujuan wisata lainnya yang dapat dikunjungi di akhir pekan. Hasil penelitian ini sejalan dengan hasil penelitian yang dilakukan oleh (Ichsan, 2015) yang mengatakan bahwa ada penurunan jumlah wisatawan yang berkunjung ke danau Kelimutu, karena kurang puasnya wisatawan yang datang berkunjung ke danau Kelimutu, hal ini dikarenakan kurang menarik dan beragamnya atraksi wisata yang disajikan, selain itu wisatawan yang berkunjung adalah repeater guest atau pengunjung yang datang berkunjung ke Ende dan kemudian diajak untuk berkunjung kembali ke danau Kelimutu, sehingga hal ini membuat mereka merasa jenuh dengan lokasi wisata yang sama.

Ada perbedaan antara hasil penelitian ini dengan hasil penelitian yang dilakukan oleh (Alkilani, Ling, \& Abzakh, 2012) (Fatharani, 2016) (Muhammad \& Artanti, 2016) yang menemukan adanya pengaruh experiential marketing terhadap kepuasan konsumen, karena adanya penerapan experiential marketing yang dirasakan, sehingga adanya kepuasaan dari konsumen pasca merasakan produk atau jasa tersebut. Menurut (Ari Wijaksono, 2018) (Alqurneh, Isa, \& Othman, 
2002) (Pattarakitham, 2015) (Koçak Alan, Tümer Kabadayi, \& Köksal, 2017) (Razak \& Sari, 2017) (Dharmawan \& Adista, 2019) juga berpendapat bahwa kepuasaan yang diperoleh wisatawan akan berdampak pada niat untuk berkunjung ulang hanya akan terjadi jika pemasar mampu memberikan pengalaman berwisata yang menyenangkan bagi wisatawan atau mampu menciptakan produk dan memberikan jasa pelayanan yang berkualitas sesuai dengan harapan konsumen. Jika semakin tinggi kepuasan yang diperoleh pengunjung, maka revisit intention (niat berkunjung ulang) pengunjung akan lebih sering lagi.

Pengaruh experiential marketing dan tourist satisfaction terhadap revisit intention adalah sebesar 0.48 dengan nilai koefisien Pvalues sebesar 0.04, hal ini menunjukkan bahwa secara simultan experiential marketing dan tourist satisfaction memiliki pengaruh yang positif dan signifikan terhadap revisit intention atau niat berkunjung ulang para wisatawan ke danau Kelimutu. Hasil penelitian ini sejalan dengan penelitian (Um, Chon, \& Ro, 2006) yang mengatakan bahwa revisit intention dianggap sebagai dampak dari kepuasaan wisatawan yang berkunjung di suatu destinasi wisata. Penelitian yang dilakukan oleh (Phillips, Wolfe, Hodur, \& Leistritz, 2013) menunjukkan bahwa citra destinasi berpengaruh terhadap persepsi para wisatawan yang secara tidak langsung akan berdampak pada kepuasaan dan keinginan untuk merekomedasikan tempat wisata tersebut ke orang lain dan memiliki niat untuk berkunjung kembali.

Kunjungan ulang dianggap sebagai indikasi positif dari kepuasan wisatawan. Pengalaman positif yang dialami oleh wisatawan selama berwisata akan memberikan dampak positif baik bagi destinasi maupun terhadap wisatawan itu sendiri. Wisatawan yang merasa puas akan pengalaman berwisatanya akan melakukan kunjungan kembali, serta kemungkinan akan merekomendasikan destinasi tersebut ke teman atau kerabat, menghasilkan efek pesan yang positif. Wisatawan yang memiliki niat untuk melakukan kunjungan ulang akan sangat logis untuk merekomendasikan destinasi tersebut.

Besarnya nilai R-square berdasarkan hasil olahan data menggunakan SEM-PLS (Partial Least Square - Stuctural Equation Modeling) dengan WarpPLS 3.0 diperoleh nilai R-square sebesar 0,60. Hal ini mengindikasikan bahwa pengaruh experiential marketing dan tourist satisfaction terhadap revisit intention atau niat berkunjung ulang sebesar $60 \%$ yang berarti bahwa $60 \%$ niat berkunjung ulang wisatawan ke danau Kelimutu dipengaruhi oleh pengalamanpengalaman yang diperoleh selama berwisata dan hal lainnya dijelaskan oleh variabel lain yang tidak dijelaskan dalam penelitian ini. Pengalaman berwisata yang berkesan telah memberi nilai yang positif bagi para wisatawan dan berdampak pada niat untuk kembali berkunjung ke danau Kelimutu.

\section{KESIMPULAN DAN SARAN}

Berdasarkan hasil analisis data diperoleh beberapa kesimpulan diantaranya; (pertama) bahwa experiential marketing berpengaruh positif dan signifikan terhadap revisit intention atau niat berkunjung ulang wisatawan ke danau Kelimutu. Pengalaman-pengalaman berwisata yang positif telah memberikan dampak yang positif juga bagi wisatawan, sehingga memiliki niat untuk melakukan kunjungan ulang ke danau Kelimutu. (kedua) disimpulkan bahwa variabel Tourist satisfaction tidak berpengaruh positif dan signifikan terhadap revisit intention atau niat berkunjung ulang ke danau Kelimutu. Hal ini menunjukkan bahwa wisatawan yang datang berkunjung ke danau Kelimutu lebih dari satu kali merasa kurang puas dengan pengalaman berwisata ke destinasi yang sama, karena adanya perasaan bosan dan juga tidak ada tempat tujuan wisata lainnya yang dapat dikunjungi diakhir pekan. Indikator dari kepuasaan wisatawan dapat dilihat dari niat wisatawan untuk merekomendasikan ke teman-teman terdekat dan menceritakan pengalaman berwisatanya kepada orang lain. (ketiga) jika dilihat dari uji simultan dapat 
disimpulkan bahwa experiential marketing dan tourist satisfaction memiliki pengaruh yang positif dan signifikan terhadap revisit intention atau niat berkunjung ulang para wisatawan ke danau Kelimutu.

Keterbatasan dalam penelitian ini adalah masih terbatasnya jumlah responden yang digunakan karena peneliti hanya mengambil wisatawan domestik sebagai responden, sehingga sulit untuk membuat perbandingan dengan wisatawan mancanegara.

\section{DAFTAR PUSTAKA}

Ali, H. (2015). Tourism Marketing. Jakarta: PT. Buku Seru.

Alkilani, K., Ling, K. C., \& Abzakh, A. A. (2012). The impact of experiential marketing and customer satisfaction on customer commitment in the world of social networks. Asian Social Science. https://doi.org/10.5539/ass.v9n1p262

Alqurneh, M., Isa, F., \& Othman, A. R. (2002). Tourism Destination Image , Satisfaction and Loyalty: A Study of the Dead Sea in Jordanian curative tourism. $1-10$.

Annisa, M. L., \& Hutasoit, G. (2018). Pengaruh Daya Saing Destinasi Wisata Terhadap Implementasi Re-Visiting Commitmen Wisatawan Objek Wisata Di Kota Palembang. JMD: Jurnal Riset Manajemen \& Bisnis Dewantara, 1(2), 77-86. https://doi.org/10.26533/jmd.v1i2.176

Ari Wijaksono, R. (2018). Pengaruh Experiential marketing Terhadap Revisit intention Melalui Kepuasan Sebagai Variabel Intervening (Studi Pada Pengunjung Trans Studio Mini Transmart Rungkut Surabaya ). Jurnal Ilmu Manajemen (JIM), 7(2), 344-353.

Badan Pusat statistik Kabupaten Ende. (2018). Kabupaten Ende Dalam Angka 2018.

Basiya, R., \& Rozak, A. H. (2012). Kualitas Dayatarik Wisata, Kepuasan Dan Niat Kunjungan Kembali Wisatawan Mancanegara di Jawa Tengah. Jurnal
Ilmiah Dinamika Kepariwisataan, XI(2), $1-12$.

Budiarto, J., \& Pancaningrum, E. (2019). Pengaruh Experiential marketing Terhadap Keputusan Pembelian Smartphone Xiaomi. JMD: Jurnal Riset Manajemen \& Bisnis Dewantara. https://doi.org/10.26533/jmd.v2i2.370

Chen, K. Y., Huan, T. C., \& Thongma, W. (2011). Developing the volunteer tourist's revisit intention model: Taiwan experience. Why the Destination Management Organization?

Çoban, S. (2012). The effects of the image of destination on tourist satisfaction and loyalty: The case of Cappadocia. European Journal of Social Sciences.

Dharmawan, D., \& Adista, D. (2019). Pengaruh Kualitas Layanan Dan Nilai Pelanggan Terhadap Kepuasan Pelanggan Grab Bike Di Universitas Krisnadwipayana. Jurnal Manajemen Bisnis Krisnadwipayana, 7(1). https://doi.org/10.35137/jmbk.v7i1.266

Fatharani, U. S. (2016). the Effect of Experiential marketing Towards Customer.

Gaol, H. L. (2014). Harris Lumban Gaol. Destinasi Pariwisata, 1(17), 31-50.

Ghozali, imam. (2016). Aplikasi Analisis Multivariete Dengan Program IBM SPSS 23 (Edisi 8). In Universitas Diponegoro.

https://doi.org/https://doi.org/10.3929/et hz-b-000238666

Handayani, E. N., \& Pratama, E. Y. (2019). Pengaruh Manajemen Hubungan Pelanggan Terhadap Kepuasan Konsumen. Jurnal Manajemen Bisnis Krisnadwipayana, 6(3). https://doi.org/10.35137/jmbk.v6i3.235

Hasan Ali, \& Haryadi. (2012). Pengaruh Persepsi Kualitas, Persepsi Value, Kepuasaan Wisatawan, dan Kunjungan Ulang Terhadap Rekomendasi Mulut Ke Mulut..pdf.

Hendarsono, G., \& Sugiharto, S. (2013). Analisa Pengaruh Experiental Marketing terhadap Minat Beli Ulang 
Konsumen. Jurnal Manajemen Pemasaran, 1(2), 1-8.

Hernández-Lobato, L., Solis-Radilla, M. M., Moliner-Tena, M. A., \& SánchezGarcía, J. (2006). Tourism destination image, satisfaction and loyalty: A study in Ixtapa-Zihuatanejo, Mexico. Tourism Geographies.

https://doi.org/10.1080/1461668060092 2039

Hui, T. K., Wan, D., \& Ho, A. (2007). Tourists' satisfaction, recommendation and revisiting Singapore. Tourism Management.

https://doi.org/10.1016/j.tourman.2006.0 8.008

Ichsan, A. R. N. . (2015). Strategi pengembangan potensi daya tarik wisata kerajinan tenun ikat di Kabupaten Ende.

Jamu, M. E. (2014). Studi Pengaruh Experiential marketing Terhadap Kunjungan Ulang Pada Daya Tarik Wisata Pulau Komodo, Manggarai Barat, Flores, Nusa Tenggara Timur.

Jeon, H. (2013). The Effect of Experiential marketing on Customer Satisfaction and Revisit intention of Beauty Salon Franchise Stores. Fashion Business. https://doi.org/10.12940/jfb.2013.17.3.1 09

Koçak Alan, A., Tümer Kabadayi, E., \& Köksal, C. (2017). Engaging Students Through Event Marketing: An Example Of University Entrepreneurship Event. Business \& Management Studies: An International Journal. https://doi.org/10.15295/bmij.v5i3.128

Kotler dan Keller. (2017). Manajemen Pemasaran, Edisi 12, Jilid 1, PT.Indeks,. Jakarta. In e - Jurnal Riset Manajemen.

Kotler, P., \& Keller, K. L. (2008). Manajemen Pemasaran, 13th Edition, Vol. 2. In Jakarta: Erlangga.

Kotler, P., \& Keller, K. L. (2009). Manajemen Pemasaran Jilid 1 Edisi Ketigabelas. In Jakarta.

Li, X. (Robert), Cheng, C. K., Kim, H., \& Petrick, J. F. (2008). A systematic comparison of first-time and repeat visitors via a two-phase online survey. Tourism Management. https://doi.org/10.1016/j.tourman.2007. 03.010

Muhammad, \& Artanti, Y. (2016). The Impact Of Experiential marketing On Word Of Mouth ( WOM ) With Customer Satisfaction As The Intervening Variable Pengaruh Experiental Marketing Terhadap Word Of Mouth ( WOM ) Dengan Kepuasan Pelanggan Sebagai Variabel Intervening. Jurnal Dinamika Manajemen, 7 (2) 2016, 182190, 7(36), 182-190.

Pattarakitham, A. (2015). The Influence of Customer Interaction, Variety, and Convenience on Customer Satisfaction and Revisit intention: A Study of Shopping Mall in Bangkok. Journal of Economics, Business and Management. https://doi.org/10.7763/joebm.2015.v3.3 36

Phillips, W. J., Wolfe, K., Hodur, N., \& Leistritz, F. L. (2013). Tourist Word of Mouth and Revisit intentions to Rural Tourism Destinations: A Case of North Dakota, USA. International Journal of Tourism Research. https://doi.org/10.1002/jtr.879

Razak, I., \& Sari, N. P. (2017). Pengaruh Kualitas Produk Dan Kualitas Layanan Terhadap Kepuasan Pelanggan. Jurnal Manajemen Bisnis Krisnadwipayana, 5(3).

https://doi.org/10.35137/jmbk.v5i3.160

Rohmat Dwi Jatmiko, \& Sri Nastiti Andharini. (2012). Analisis Experiential marketing Dan Loyalitas Pelanggan Jasa Wisata (Studi pada Taman Rekreasi Sengkaling Malang). Jurnal Manajemen Dan Kewirausahaan.

Schmitt, Bernd. (2007). Customer Experience Management : A Revolutionary Approach to Connecting with Your Customers. In Wiley.

Schmitt, Bh. (1999). Experiential marketing, How to get customers to sense, feel, think, act, and relate to your company 
and brands. New York. https://doi.org/10.1362/0267257997848 70496

Sholihin, M., \& Ratmono, D. (2013). Analisis SEM-PLS Dengan WarpPLS 3.0 untuk hubungan nonlinear dalam penelitian sosial dan bisnis. Yogyakarta: Penerbit Andi.

Som, A. P. M., \& Badarneh, M. B. (2011). Tourist satisfaction and repeat visitation; toward a new comprehensive model. World Academy of Science, Engineering and Technology.

Sugiyono. (2016). Metode Penelitian Manajemen. Bandung: Alfabeta.

Tosun, C., Dedeoğlu, B. B., \& Fyall, A. (2015). Destination service quality, affective image and revisit intention: The moderating role of past experience. Journal of Destination Marketing and Management, 4(4), 222-234. https://doi.org/10.1016/j.jdmm.2015.08. 002

Um, S., Chon, K., \& Ro, Y. H. (2006). Antecedents of revisit intention. Annals of Tourism Research. https://doi.org/10.1016/j.annals.2006.06 .003
Wong, C. keung S., \& Yan Kwong, W. Y. (2004). Outbound tourists' selection criteria for choosing all-inclusive package tours. Tourism Management. https://doi.org/10.1016/j.tourman.2003. 06.002

Wulanjani, H., \& Derriawan, D. (2017). Dampak Utilitarian Value Dan Experiential marketing Terhadap Customer Satisfaction Dan Revisit intention. Jurnal Riset Manajemen Dan Bisnis (JRMB) Fakultas Ekonomi UNIAT.

https://doi.org/10.36226/jrmb.v2i2.42

Yoon, Y., \& Uysal, M. (2005). An examination of the effects of motivation and satisfaction on destination loyalty: A structural model. Tourism Management. https://doi.org/10.1016/j.tourman.2003. 08.016

Žabkar, V., Brenčič, M. M., \& Dmitrović, T. (2010). Modelling perceived quality, visitor satisfaction and behavioural intentions at the destination level. Tourism Management. https://doi.org/10.1016/j.tourman.2009. 06.005 